\title{
Foaming of Filled Polyurethanes for Fabrication of Porous Anode Supports for Intermediate Temperature-Solid Oxide Fuel Cells
}

\author{
Alberto Rainer, ${ }^{\dagger}$ Francesco Basoli, Silvia Licoccia, and Enrico Traversa ${ }^{\star \dagger}$ \\ Department of Chemical Science and Technology, University of Rome "Tor Vergata" 00133-Rome, Italy
}

\begin{abstract}
The development of a tailored microstructure is considered essential for the development of anode-supported intermediate temperature-solid oxide fuel cells (IT-SOFCs) as it is expected to enhance kinetics at the triple phase boundary. In this study, the application of an in situ foaming technique for the preparation of Ni-yttria-stabilized zirconia (YSZ) cellular solids as an anode support for IT-SOFCs is presented. The cermet microstructure is dependent on the preparative route followed. The presence of contaminants in the commercial template precursor was found to be detrimental for electrical properties. A highpurity polyurethane was then formulated, and tailored Ni-YSZ foams were obtained with $87 \%$ porosity. The foam microstructure is characterized by a hierarchical architecture, with interconnected networks of Ni and YSZ particles, large pores related to the open cell structure, and a submicron porosity of the structural trabecular network, with a conductivity value of $80 \mathrm{~S} / \mathrm{cm}$ at $700^{\circ} \mathrm{C}$.
\end{abstract}

\section{Introduction}

Solid oxide fuel cells (SOFCs) are emerging as a practical and versatile energy conversion system. ${ }^{1}$ In spite of the fact that SOFC technology has been proved, its high costs have limited implementation. ${ }^{2}$ Lowering the SOFC working temperature from $1000^{\circ}$ to $750^{\circ} \mathrm{C}$ or less limits the problems related to high-temperature deterioration, such as thermal stresses, interfacial diffusion between electrolyte, electrodes and interconnects, and fast electrode aging due to sintering processes. ${ }^{3-5}$ Moreover, a sufficiently low operating temperature enables the use of cheap ferritic steel for interconnects, instead of more expensive ceramic materials or chromium alloys. ${ }^{6}$

There are two main approaches for lowering SOFC working temperature. Reducing the thickness of the conventional yttriastabilized zirconia (YSZ) electrolyte results in decreasing ohmic resistance $^{7-9}$ On the other hand, one can use alternative electrolyte materials having a larger ionic conductivity than YSZ at intermediate temperatures, such as Gd- or Sm-doped ceria ${ }^{10,11}$ or Sr- and Mg-doped lanthanum gallate. ${ }^{12-15}$ Innovative electrolytes are materials whose properties have not yet been fully investigated for practical applications. Industry prefers to continue to use YSZ, a fully investigated and reliable material, although the fabrication of thin dense films will be needed. ${ }^{16}$ In fact, operation at $700^{\circ} \mathrm{C}$ with YSZ requires a thickness of 15 $\mu \mathrm{m} .{ }^{17}$ Such films do not provide the required mechanical strength; therefore, it is necessary to deposit YSZ films on a supporting substrate, usually an anodic support made of porous $\mathrm{Ni}-$ YSZ cermet. $^{18}$ One of the technical problems of this approach is the creation of defects (cracks or film spalling) because

G. Messing—contributing editor

Manuscript No. 21386. Received January 15, 2006; approved February 24, 2006. Presented at the 9th International Ceramic Processing Science Symposium, Coral Springs, FL, Jan. 8-11, 2006.

${ }^{*}$ Member, American Ceramic Society.

${ }^{\dagger}$ Author to whom correspondence should be addressed. e-mail: traversa@uniroma2.it of the different thermal expansion coefficients of YSZ and the cermet.

However, lowering the working temperature of SOFCs also has the drawback of negatively affecting the kinetics of charge transfer reactions at the electrolyte-electrode interfaces, resulting in an increase in the electrode overpotential. The presence of a large electrolyte-electrode-air triple phase boundary (TPB) allows to limit overpotential. ${ }^{19,20}$ Tailoring the microstructure of the electrode materials, both during powder synthesis and the fabrication process of the porous electrode layers, can lead to a large TPB for performance improvement. ${ }^{2-23}$

The aim of this study was to develop Ni-YSZ foams as anodic substrates for intermediate temperature-solid oxide fuel cells (IT-SOFCs). Cellular ceramics are very interesting for a wide range of applications, because of their high porosity, high gas permeability, good mechanical stiffness, and good thermal shock resistance. ${ }^{24}$ These characteristics are excellent for application as anodic support, including compliance during the sintering of the YSZ film, provided that percolating networks of $\mathrm{Ni}$ and YSZ can be obtained. In principle, it should be possible to tailor the microstructure of the foams to improve the TPB, by tailoring it to have a submicron porosity within the cell walls and large open pores for easy gas flow. We propose to either foam the NiO-YSZ structure or to fabricate YSZ foams and subsequently impregnate the surface with Ni. Cellular ceramics been have already studied for SOFCs. For instance, strontiumdoped lanthanum manganite (LSM) foams have been applied as cathode-side current collectors, ${ }^{25}$ and composite Ni-YSZ anodes have been fabricated by incorporating a Ni foam into a porous YSZ layer. ${ }^{26}$ Several processes have been developed for the fabrication of ceramic foams, such as organic template replication, ${ }^{25}$ modified gelcasting, ${ }^{27}$ freeze-drying, ${ }^{28}$ and in situ foaming and polymerization. ${ }^{29,30}$ In this work, in situ polymerization of a ceramic-loaded polyurethane (PU) foam was selected for the fabrication of cellular layers.

\section{Experimental Procedure}

\section{(1) Preparation of Ni-YSZ Foams}

Two sets of samples were prepared, using either a commercial PU system (samples A), or a research-grade PU system (samples B). All the preparative procedures were carried out at room temperature.

Type A samples were prepared by manually dispersing a commercial NiO-YSZ powder $\left(70 \mathrm{wt} \% \mathrm{NiO}-30 \mathrm{wt} \% \mathrm{YSZ}, d_{50}\right.$ $<1.0 \mu \mathrm{m}, d_{95}<5.4 \mu \mathrm{m}$, specific surface area $=5.4 \mathrm{~m}^{2} / \mathrm{g}$, Praxair, Danbury, CT) at selected volume percentages (from 10 to 50 vol\%) in a commercial PU system for rigid foams (Espak, Prochima, Pesaro, Italy). The product consisted of two components, identified as polymethylene polyphenylisocyanate and a polyol with functionality 2 or higher. A catalyst and water were premixed to the polyol by the supplier. Polymerization reaction started immediately after mixing the two components.

For the preparation of sample $\mathrm{B}$, the same $\mathrm{NiO}-\mathrm{YSZ}$ powder was used at $20 \mathrm{vol} \%$ loading. PU precursors were polymethylene polyphenylisocyanate (Voranate M220, Dow Chemicals, Midland, MI), poly(ethylene glycol) (PEG 200, Aldrich, 

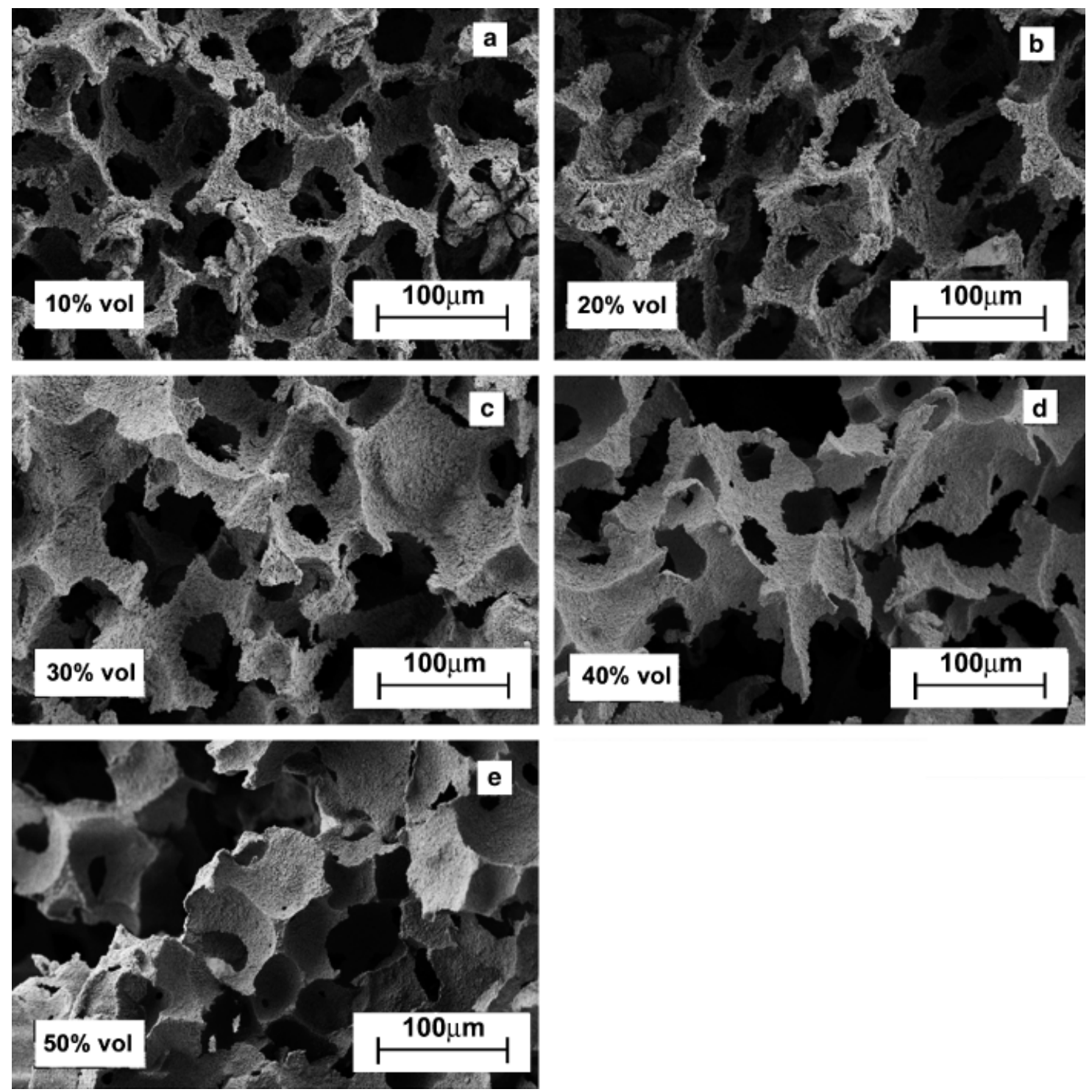

Fig. 1. Field emission scanning electron microscopy micrographs of the NiO-yttria-stabilized zirconia foams (samples $\mathrm{A}$ ) sintered at $1350^{\circ} \mathrm{C}$ for $5 \mathrm{~h}$, obtained with different amounts of ceramic loading: 10 (a), 20 (b), 30 (c), 40 (d), and $50 \mathrm{vol} \%$ (e).

St. Louis, MO), and polyoxyethylene sorbitan monooleate (Tween 80, Fluka Chemie, Buchs, Switzerland) in an 8:4:1 volume ratio. The ceramic powder was dispersed in the polymeric blend by means of manual stirring. Typically, mixtures of total weight $2.5 \mathrm{~g}$ were processed at a time. One milligram of 1,4-

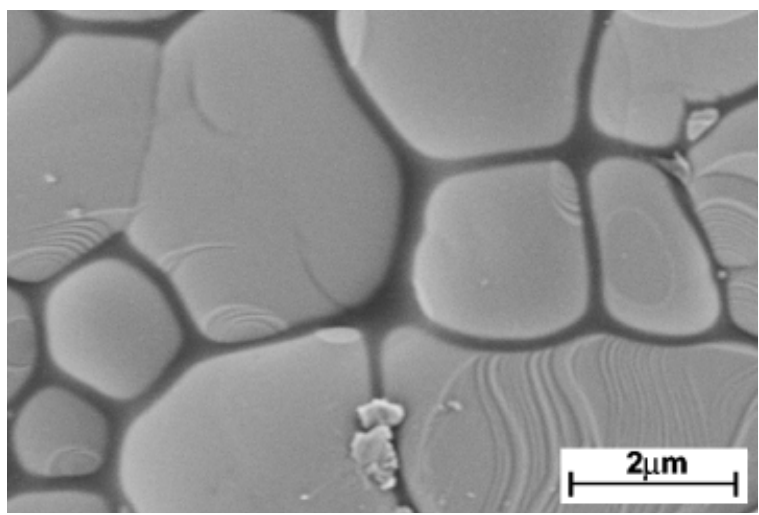

Fig. 2. Field emission scanning electron microscopy micrograph of the sintered yttria-stabilized zirconia foam prepared using commercial polyurethane: detail of the wall surface. diazabicyclooctane (Dabco, $>98 \%$, Aldrich) and $10 \mu \mathrm{L}$ water were added to initiate polymerization and foaming reaction.

In both experiments, the polymerization of the PU resin was performed in an open Teflon mold to allow full expansion of the foam. After the polymerization reaction, bar-shaped samples (approximately $10 \times 5 \times 5 \mathrm{~mm}$ ) were manually cut from the green body by means of a blade. Both foams were sintered in air at $1350^{\circ} \mathrm{C}$ for $5 \mathrm{~h}$. Reduction of $\mathrm{NiO}$ to $\mathrm{Ni}$ was performed at $700^{\circ} \mathrm{C}$ for $2 \mathrm{~h}$ in $5 \% \mathrm{H}_{2} / \mathrm{Ar}$ atmosphere.

\section{(2) Preparation of YSZ Foams and their Impregnation with $\mathrm{Ni}$}

YSZ scaffolds were manufactured using the preparation technique described for sample $\mathrm{B}$, starting with a commercial YSZ powder (TZ8Ys, slip-casting grade, $d_{95}<2 \mu \mathrm{m}$, Tosoh, Tokyo, Japan). The foams were sintered at $1500^{\circ} \mathrm{C}$ for $5 \mathrm{~h}$.

A saturated aqueous solution of $\mathrm{Ni}$ acetate $(99 \%$, Carlo Erba, Milan, Italy) and urea (99\%, Aldrich) was prepared. Porous YSZ foams were immersed in this solution. Heating to about $80^{\circ} \mathrm{C}$ led to the formation of a gel in the foam cells. Impregnated foams were heated to $700^{\circ} \mathrm{C}$ for $2 \mathrm{~h}$ to form $\mathrm{NiO}$. The foams were treated in $5 \% \mathrm{H}_{2} / \mathrm{Ar}$ atmosphere at $800^{\circ} \mathrm{C}$ to perform the reduction of $\mathrm{NiO}$ to $\mathrm{Ni}$. 

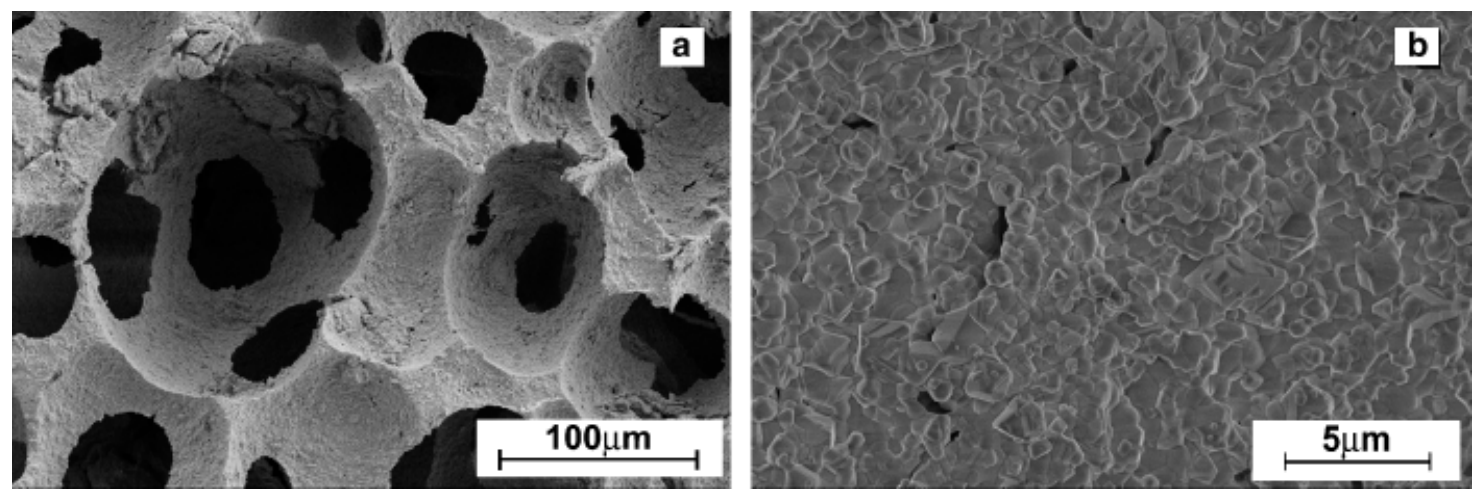

Fig. 3. Field emission scanning electron microscopy micrographs of the sintered NiO-yttria-stabilized zirconia foam (sample B) (a), and of a detail of the wall surface $(b)$.
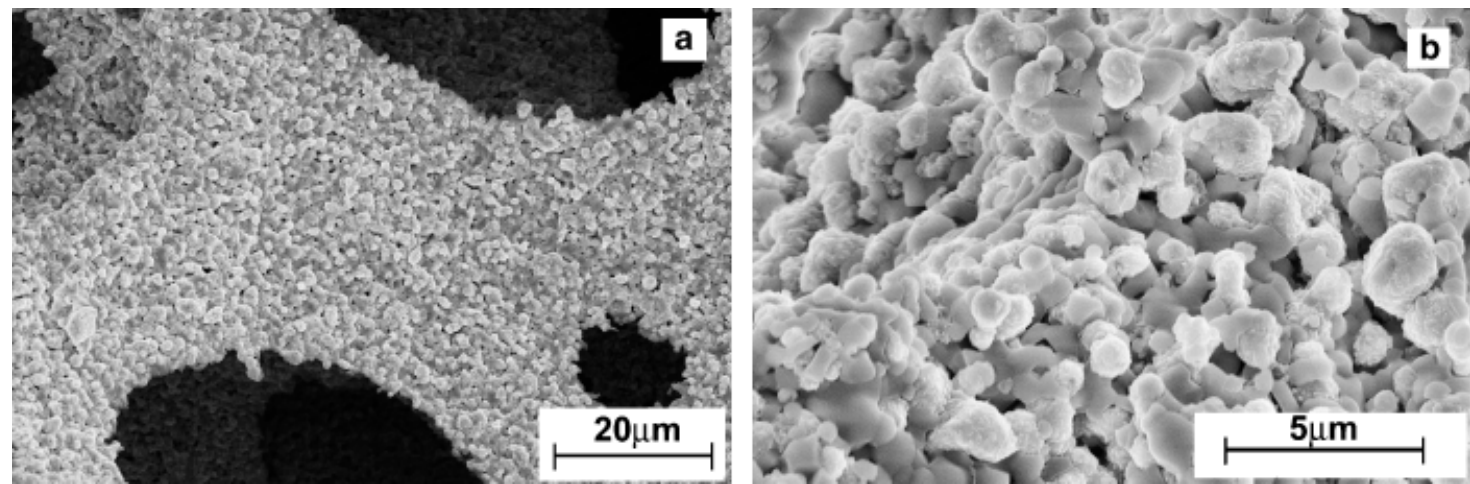

Fig. 4. Field emission scanning electron microscopy micrographs of Ni-yttria-stabilized zirconia foam (sample $\mathrm{B}$ ) after reduction in $\mathrm{H}_{2} / \mathrm{Ar}$ atmosphere (a). Detail of the wall surface (b).

The impregnation process was repeated several times to achieve percolation of $\mathrm{Ni}$ particles.
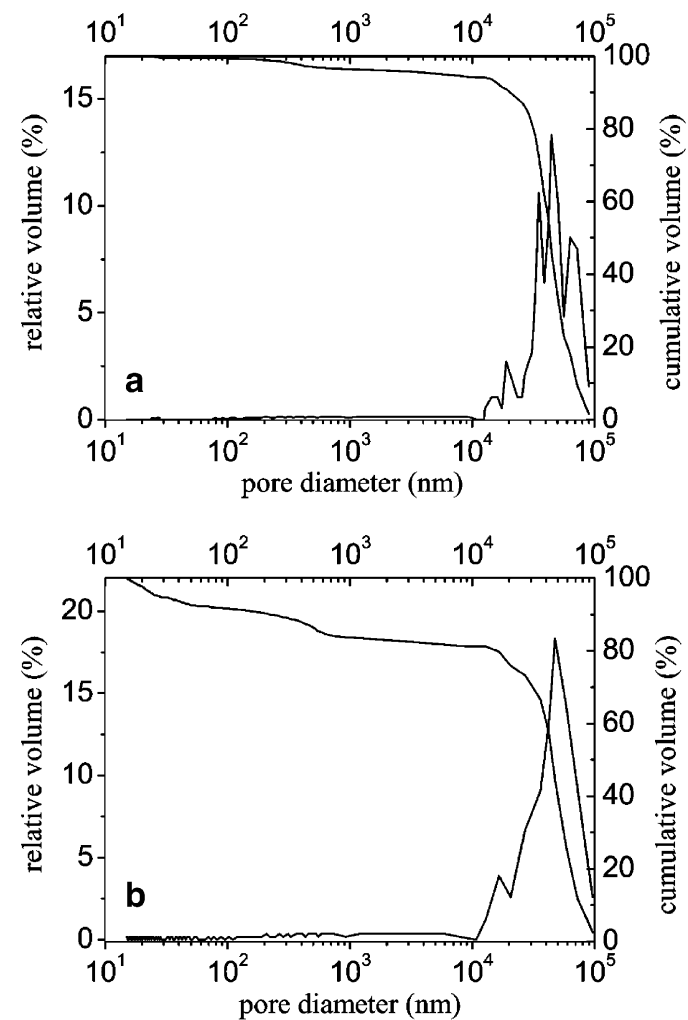

Fig. 5. Pore size distribution of the NiO-yttria-stabilized zirconia foam (sample B) (a) and the Ni-yttria-stabilized zirconia foam (sample B) after reduction (b).

\section{(3) Material Characterization}

Simultaneous thermogravimetric and differential thermal analysis (TG-DTA) (STA 419, Netzsch, Selb, Germany) was performed on green bodies to investigate the oxidative degradation of PU matrix.

ATF-FTIR investigation (Nicolet 8700, Thermo Electron Corporation, Waltham, MA) was performed on the PU matrix for contaminant detection.

Morphological characterization of the foams was performed by field emission scanning electron microscopy (FE-SEM, Supra 1535, LEO Electron Microscopy, Oberkochen, Germany).

Porosity investigation was performed using mercury porosimetry (Porosimeter 2000, Carlo Erba).

Four-point DC conductivity measurements were performed using a digital electrometer (DMM 2000, Keithley, Cleveland, $\mathrm{OH}$ ) on bar-shaped, reduced samples. Measurements were performed in an $\mathrm{Ar}$ atmosphere to prevent re-oxidation of $\mathrm{Ni}$.

\section{Results and Discussion}

\section{(1) Preparation of Ni-YSZ Foams from a Commercial NiO-YSZ Powder}

The chemistry of PU is based on the reaction between a diisocyanate and a polyol, which occurs in the presence of a catalyst. For the fabrication of foams, water is used as a foaming agent, as it reacts with the isocyanate group during the polymerization reaction, producing carbon dioxide that expands the polymer matrix, yielding a cellular structure. Dispersing a ceramic powder in the liquid reagents before polymerization enables the production of a ceramic-loaded polymeric foam.

To obtain an inorganic foam, polymer burnout at $650^{\circ} \mathrm{C}$ was assessed from TG-DTA analysis. Below this temperature, a rapid gas release as a result of the oxidative decomposition of the PU matrix yields a cellular material. However, if the process is not controlled, it might cause the collapse or cracking of the 

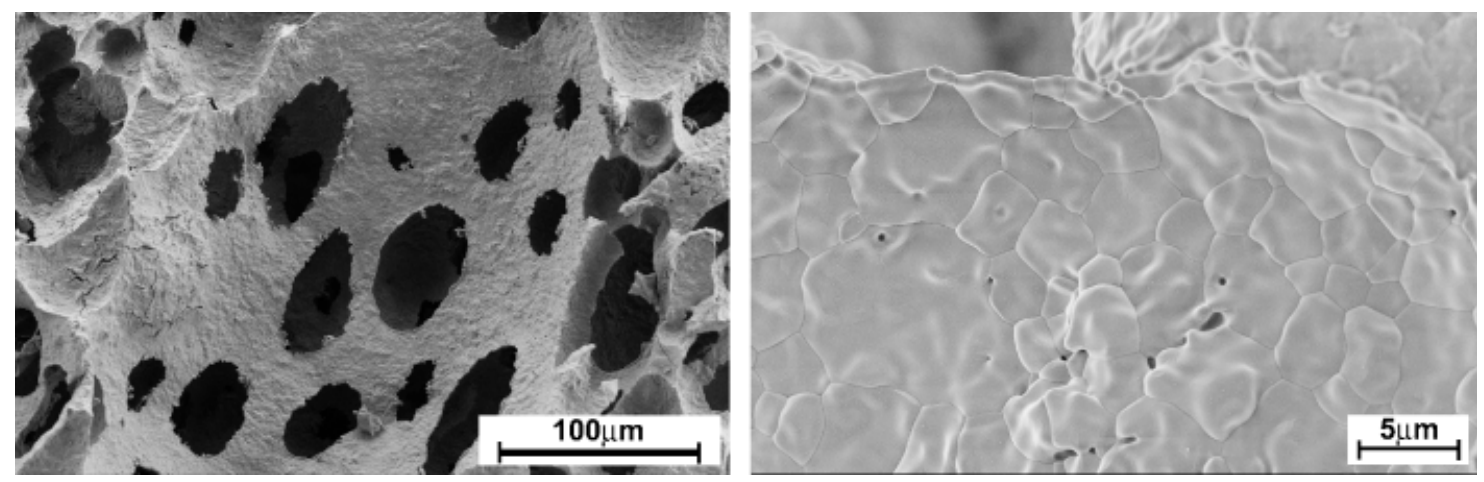

Fig. 6. Field emission scanning electron microscopy micrographs of the yttria-stabilized zirconia foam after sintering at $1500^{\circ} \mathrm{C}$ for $10 \mathrm{~h}$, prepared with Si-free polyurethane.

green body cellular structure before densification of the cell walls. Therefore, a heating rate of $1 \mathrm{~K} / \mathrm{min}$ was chosen for the sintering processes.

Figure 1 shows micrographs of $\mathrm{NiO}-\mathrm{YSZ}$ foams prepared with the commercial PU (samples A) with different ceramic loadings $(10,20,30,40$, and $50 \mathrm{vol} \%)$, after sintering at $1350^{\circ} \mathrm{C}$ for $5 \mathrm{~h}$. Samples prepared with 10 and $20 \mathrm{vol} \%$ of ceramic powder (Figs. 1(a) and (b)) showed an open cell structure, with regular porosity in the 100-200 $\mu \mathrm{m}$ range and thin trabecular elements. Ceramic loadings above $30 \mathrm{vol} \%$ led to a disruption of the regular cell structure (Figs. 1(c)-(e)). The sample prepared with $20 \mathrm{vol} \%$ ceramic loading (Fig. 1(b)) was found to possess the best compromise between mechanical stability and homogeneous foam structure. For this sample, the total porosity was $72 \%$.

In order to evaluate the electrical properties of the inorganic foam, a reduction process in $\mathrm{H}_{2} / \mathrm{Ar}$ atmosphere was performed to obtain a Ni-YSZ cermet. Severe changes were observed in samples A after reduction. The mechanical strength was lost, and the electrical conductivity was very low. Some YSZ foams were also prepared with the commercial PU. Figure 2 shows the wall of an YSZ foam sintered at $1500^{\circ} \mathrm{C}$ for $5 \mathrm{~h}$. The presence of a glassy phase segregated at the grain boundaries on the cell walls could be clearly observed. EDX microanalysis showed that this segregated phase was mainly silica. Si was determined to derive from Si-containing surfactants and foam stabilizers in the commercial PUs. During the sintering process, the Si contaminants formed a glassy layer at the grain boundary of the ceramic body, which is detrimental for electrical applications. Because of the deleterious effect of the silicate glass on properties, a new formulation of a contaminant-free PU system was developed. High-purity reagents were selected, using polyoxyethylene sorbitan monoleate as a Si-free surfactant. The absence of silicon compounds in the new PU system was confirmed by attenuated total reflection fourier transform infrared spectroscopy (ATR-FTIR) investigations. Sample B was thus prepared with the Si-free PU.

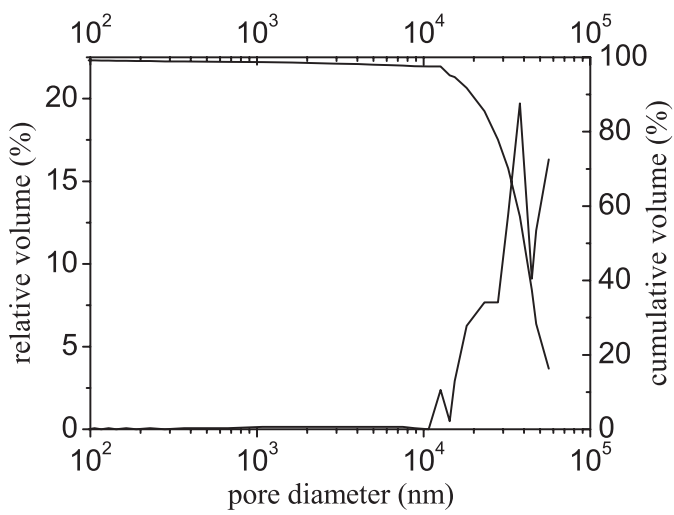

Fig. 7. Pore size distribution of the yttria-stabilized zirconia foam.
Figure 3 shows typical micrographs of sample B after sintering at $1350^{\circ} \mathrm{C}$ for $5 \mathrm{~h}$. Although the absence of Si-based foam stabilizers resulted in a less homogeneous foam structure than that observed for sample A, an open cell structure with thin walls and good sintering of the trabecular network can be observed. Figure 3(b) shows that the cell walls were relatively dense, with sparse porosity.

Structural integrity was preserved after the reduction process. The formation of $\mathrm{Ni}$ and the disappearance of $\mathrm{NiO}$ were confirmed with X-ray diffraction (XRD) measurements (results not shown). Figure 4 shows micrographs of the Ni-YSZ cermet foams. The change in volume associated with the reduction in $\mathrm{NiO}$ caused a residual porosity in the trabeculae of the foam, as shown in Fig. 4(b). Thus, the cermets showed a bimodal pore size distribution; together with a larger porosity, in the $100 \mu \mathrm{m}$ range, ascribed to the foam structure, a porosity in the submicron range in the foam walls was evidenced, because of the reduction of $\mathrm{NiO}$. This was confirmed by pore size distribution analysis performed on the foams before and after reduction in hydrogen, as shown in Fig. 5. After reduction, the pore size distribution changed because of the Ni volume variation, in good agreement with SEM observations. This can best be seen by comparing the cumulative volume plots. A total porosity of $74 \%$ was measured for the $\mathrm{NiO}-$ YSZ sample, with $5 \%$ of the pore volume below $1 \mu \mathrm{m}$. The Ni-YSZ sample showed an increased total porosity, which was found to be $87 \%$. For this sample, the volume of pores below $1 \mu \mathrm{m}$ was $14 \%$.

The conductivity of Ni-YSZ foams was evaluated by means of four-point DC measurements. Owing to the difficulties in calculating the geometric parameters, the measured resistance values were correlated to the apparent dimensions of the barshaped samples. With this assumption, a conductivity value of $80 \mathrm{~S} / \mathrm{cm}$ at $700^{\circ} \mathrm{C}$ was measured. In a previous study, the same anodic powder was used for the preparation of standard tapecast anodes. ${ }^{31}$ Conductivity measurements performed under similar conditions on these anodes gave values of $250 \mathrm{~S} / \mathrm{cm}$ at $700^{\circ} \mathrm{C}$. Although the conductivity of the foams is significantly lower with respect to the standard anode, because of the extreme porosity of the foam, the high conductivity indicates that good percolation of the $\mathrm{Ni}$ phase in the cermet foam structure was achieved.

\section{(2) Preparation of YSZ Foams and their Impregnation with $\mathrm{Ni}$}

Figure 6 shows the FE-SEM micrograph of the YSZ scaffold foam after sintering at $1500^{\circ} \mathrm{C}$ for $10 \mathrm{~h}$. A regular foam structure with open cells in the $100 \mu \mathrm{m}$ range can be observed. The plot of the cumulative porosity volume indicated that almost $100 \%$ of the total porosity is above $10 \mu \mathrm{m}$ (Fig. 7).

Impregnation of the YSZ foams was performed by immersing the ceramic foam in a saturated aqueous solution of Ni acetate and urea. Heating the solution to $80^{\circ} \mathrm{C}$ led to the formation of a gel, with possible formation of polyamidic groups between acetate and urea. After calcinations at $700^{\circ} \mathrm{C}$, the surface of the 

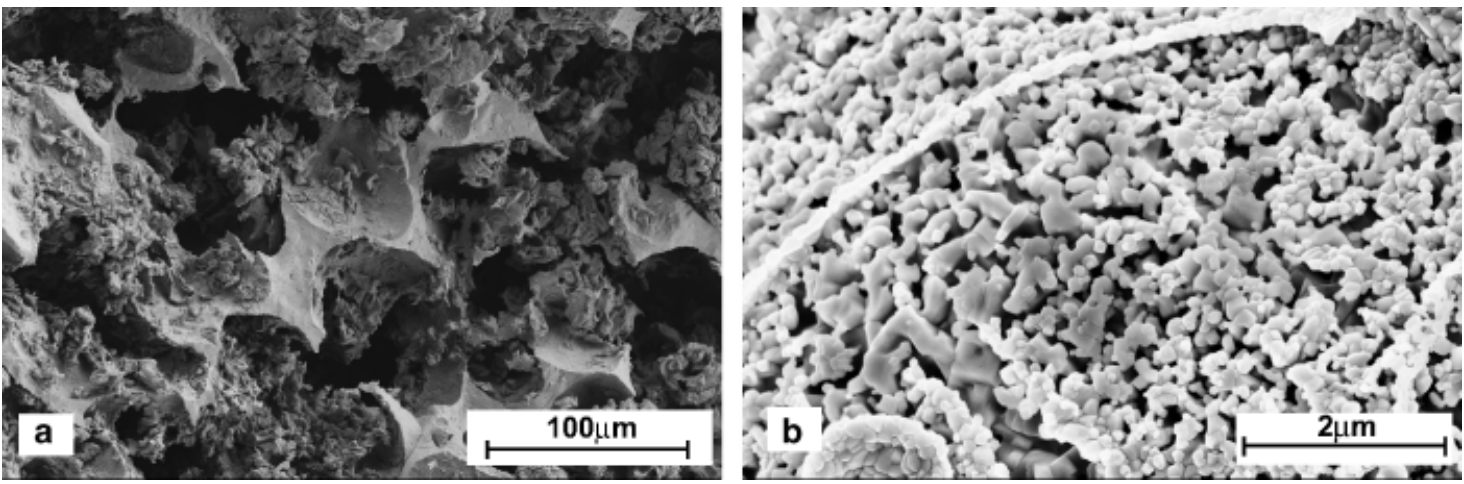

Fig. 8. Field emission scanning electron microscopy micrographs of the NiO-yttria-stabilized zirconia foam after 3 impregnations (a) and of the NiO morphology at higher magnification (b).

cells was covered with a layer of $\mathrm{NiO}$ nanoparticles, as confirmed by XRD measurements. This process led to the formation of a layer of $\mathrm{NiO}$ nanoparticles that was discontinuous. Therefore, the impregnation process was repeated several times to achieve a continuous $\mathrm{NiO}$ deposition. Figure 8 shows the microstructure of the NiO-YSZ foam obtained after repeating the impregnation process three times. The structural continuity of the YSZ network can be clearly observed, while a thick layer of $\mathrm{NiO}$ particles covers the surface of the YSZ skeleton.

The foams maintained their structural integrity after reduction of $\mathrm{NiO}$ to $\mathrm{Ni}$. The morphology of the Ni nanoparticle deposit appeared homogeneous, as shown in Fig. 9, but the coverage of the ionic conductor foam surface was not complete. Such a morphology is very encouraging in terms of TPB. However, conductivity measurements performed using four-point DC measurements did not give satisfactory results. The conductivity was orders of magnitude lower than the value measured for Ni-YSZ foams prepared with the previous processing method using an anodic powder. This behaviour can be ascribed to the loose particle-to-particle contact achieved by the Ni layer after reduction, and the relatively low volume fraction of the $\mathrm{Ni}$ deposit with respect to the ceramic phase. Although the microstructure obtained is promising, further work is needed to find the processing parameters that will result in percolation of the $\mathrm{Ni}$ particle.

\section{Conclusions}

A one-pot process for the preparation of ceramic foams for ITSOFC applications was developed. The process allows the preparation of cellular solids starting from a ceramic powder and a PU by means of in situ foaming and polymerization of the polymer templating matrix. Using commercial PU led to silica contamination in the foams, which was prevented by using a silicon-free PU prepared in our laboratory.

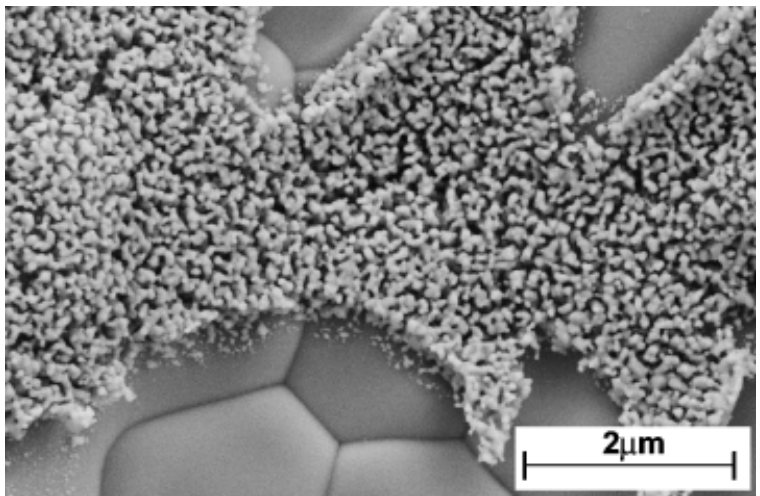

Fig. 9. Field emission scanning electron microscopy micrograph of the layer of Ni nanoparticles on the yttria-stabilized zirconia skeleton foam after reduction in $\mathrm{H}_{2} / \mathrm{Ar}$ atmosphere.
The two processing routes used led to different microstructures of the cermets. Preparing the foams from a commercial $\mathrm{NiO}-\mathrm{YSZ}$ powder resulted in foams with an intimate contact between the two phases (Ni and YSZ). These samples were tailored to show a microstructure with a hierarchical architecture, with interconnected networks of $\mathrm{Ni}$ and YSZ particles, large pores related to the open cells structure, and a submicron porosity of the structural trabecular network. Preparing a YSZ foam with subsequent impregnations with $\mathrm{NiO}$ gave samples in which the metal phase layer of $\mathrm{Ni}$ nanoparticles on the skeleton of the ceramic ionic conductor foam was discontinuous.

The morphological differences in the samples considerably influenced the electrical conductivity. Samples prepared by impregnation did not give satisfactory results, while samples prepared with $\mathrm{NiO}-\mathrm{YSZ}$ powder showed a conductivity value of 80 $\mathrm{S} / \mathrm{cm}$ at $700^{\circ} \mathrm{C}$. This value seems promising for application as an anode support for SOFC fabrication.

\section{Acknowledgment}

The authors wish to thank Prof. Marcella Trombetta (Interdisciplinary Research Center, University "Campus Bio-Medico", Rome, Italy) for ATR/FTIR investigations.

\section{References}

${ }^{1}$ A. Boudghene Stambouli and E. Traversa, "Solid Oxide Fuel Cells (SOFCs): A Review of an Environmentally Clean and Efficient Source of Energy," Renew. Sust. Energ. Rev., 6, 433-55 (2002).

${ }^{2}$ M. C. Williams, J. P. Strakey, and W. A. Surdoval, "U.S. Department of Energy's Solid Oxide Fuel Cells: Technical Advances," Int. J. Appl. Ceram. Technol., 2 [4] 295-300 (2005).

B. C. H. Steele and A. Heinzel, "Materials for Fuel-Cell Technologies," Nature (London), 414, 345-52 (2001)

${ }^{4}$ H. Tu and U. Stimming, "Advances, Aging Mechanisms and Lifetime in SolidOxide Fuel Cells," J. Power Sources, 127, 284-93 (2004).

${ }^{5}$ J. P. P. Huijsmans, P. F. van Berkel, and G. M. Christie, "Intermediate Temperature SOFC - a Promise for the 21st Century," J. Power Sources, 71, 107-10 (1998).

${ }^{6}$ J. W. Fergus, "Metallic Interconnects for Solid Oxide Fuel Cells," Mater. Sci. Eng. A, 397, 271-83 (2005).

J. Will, A. Mitterdorfer, C. Kleinlogel, D. Perednis, and L. Gauckler, "Fabrication of Thin Electrolytes for Second-Generation Solid Oxide Fuel Cells," Solid State Ionics, 131, 79-96 (2000)

${ }^{8}$ Y. Jiang and A. V. Virkar, "A High Performance, Anode-Supported Solid Oxide Fuel Cell Operating on Direct Alcohol," J. Electrochem. Soc., 148, A706-9 (2001)

${ }^{9}$ Y. Matsuzaki and I. Yasuda, "Electrochemical Properties of a SOFC Cathode in Contact a Chromium-Containing Alloy Separator," Solid State Ionics, 152-153, 463-7 (2002)

${ }^{10}$ M. Mogensen, N. M. Sammes, and G. A. Tompsett, "Physical, Chemical and Electrochemical Properties of Pure and Doped Ceria," Solid State Ionics, 129, 63-94 (2000).

${ }^{11}$ B. C. H. Steele, "Appraisal of $\mathrm{Ce}_{1-y} \mathrm{Gd}_{y} \mathrm{O}_{2-y / 2}$ Electrolytes for IT-SOFC Operation at $500^{\circ} \mathrm{C}, "$ Solid State Ionics, 129, 95-110 (2000).

${ }^{12}$ T. Ishihara, H. Matsuda, and Y. Takita, "Doped $\mathrm{LaGaO}_{3}$. Perovskite-Type Oxide as a New Oxide Ionic Conductor," J. Am. Chem. Soc., 116, 3801-3 (1994).

${ }^{13}$ M. Feng and J. B. Goodenough, "A Superior Oxide-Ion Electrolyte," Eur. J. Solid State Inorg. Chem., 31, 663-72 (1994). 
${ }^{14}$ J. Akikusa, K. Adachi, K. Hoshino, T. Ishihara, and Y. Takita, "Development of a Low Temperature Operation Solid Oxide Fuel Cell," J. Electrochem. Soc., 148, A1275-8 (2001).

${ }^{15}$ R. Polini, A. Pamio, and E. Traversa, "Effect of Synthetic Route on Sintering Behaviour, Phase Purity and Conductivity of $\mathrm{Sr}$ - and $\mathrm{Mg}$-Doped $\mathrm{LaGaO}_{3}$ Perovskites," J. Eur. Ceram. Soc., 24, 1365-70 (2004).

${ }^{16}$ P. Singh and N. Q. Minh, "Solid Oxide Fuel Cells: Technology Status," Int. J. Appl. Ceram. Technol., 1 [1] 5-15 (2004).

${ }^{17}$ B. C. H. Steele, "Oxygen Ion Conductors"; pp. 402-46 in High Conductivity Solid Ionic Conductors-Recent Trends and Applications (Chapter 15), Edited by T. Takahashi. World Scientific, London, U.K., 1989.

${ }^{18}$ P. Charpentier, P. Fragnaud, D. M. Schleich, and E. Gehain, "Preparation of Thin Film SOFCs Working at Reduced Temperature," Solid State Ionics, 135, 373-80 (2000)

${ }^{19}$ M. Brown, S. Primdahl, and M. Mogensen, "Structure/Performance Relations for Ni/Yttria-Stabilized Zirconia Anodes for Solid Oxide Fuel Cells," J. Electrochem. Soc., 147, 475-8 (2000).

${ }^{20}$ K. Sasaki, J.-P. Wurth, R. Gschwend, M. Gödickemeier, and L. J. Gauckler, "Microstructure-Property Relations of Solid Oxide Fuel Cell Cathodes and Current Collectors," J. Electrochem. Soc., 143, 530-43 (1996).

${ }^{21}$ V. Esposito, C. D'Ottavi, S. Ferrari, S. Licoccia, and E. Traversa, "New Chemical Routes for Preparation of Ultrafine NiO-YSZ Powders for SOFC Anode Applications"; pp. 643-52 in The Electrochemical Society Proceeding Series, Vol. 2003-07, Solid Oxide Fuel Cells VIII (SOFC VIII), Edited by S. C. Singhal and M. Dokiya. The Electrochemical Society, Pennington, NJ, 2003.

${ }^{22}$ D. Z. de Florio, R. Muccillo, V. Esposito, E. Di Bartolomeo, and E. Traversa, "Preparation and Electrochemical Characterization of Perovskite/YSZ Ceramic Films," J. Electrochem. Soc., 152, A88-92 (2005).
${ }^{23}$ F. C. Fonseca, D. Z. de Florio, V. Esposito, E. Traversa, E. N. S. Muccillo, and R. Muccillo, "Mixed Ionic-Electronic Composite for SOFC Anodes with High Electrical Conductivity," J. Electrochem. Soc., 153, A354-60 (2006).

${ }^{24}$ M. Scheffler and P. Colombo (eds.) Cellular Ceramics: Structure, Manufacturing, Properties and Applications. Wiley-VCH, Weinheim, Germany, 2005.

${ }^{25}$ J. Will and L. J. Gauckler, "Ceramic Foams as Current Collectors in Solid Oxide Fuel Cells (SOFC): Electrical Conductivity and Mechanical Behaviour"; pp. 757-64 in The Electrochemical Society Proceeding Series, Vol. 1997-40, Solid Oxide Fuel Cells V (SOFC V), Edited by U. Stimming, S. C. Singhal, H. Tagawa, and W. Lehnert. The Electrochemical Society, Pennington, NJ, 1997.

${ }^{26}$ S. F. Corbin, R. M. Clemmer, and Q. Yang, "Co-Sintering Behaviour of Porous Ni-YSZ Composite SOFC Anodes"; pp. 331-40 in Prooceedings of the 29th International Conference on Advanced Ceramics and Composites, Vol. 26-4, Ceramic Engineering and Science Proceedings, Edited by N. P. Bansal, D. Zhu, and W. M. Kriven. American Ceramic Society, Westerville, OH, 2005.

${ }^{27}$ P. Sepulveda, "Gelcasting Foams for Porous Ceramics," Am. Ceram. Soc. Bull., 76, 61-5 (1997).

${ }^{28}$ T. Fukasawa, Z. Y. Deng, M. Ando, T. Ohji, and Y. Goto, "Pore Structure of Porous Ceramics Synthesized from Water-Based Slurry by Freeze-Dry Process," $J$. Mater. Sci., 36, 2523-7 (2001).

${ }^{29}$ S. J. Powell and J. R. G. Evans, "The Structure of Ceramic Foams Prepared from Polyurethane-Ceramic Suspensions," Mater. Manu. Proc., 10 [4] 757-71 (1995).

${ }^{30}$ S. Roitti, A. Rainer, and V. Sergo, "Catalitic Properties of Ce-TZP Ceramic Foams," Key Eng. Mater., 264-268, 2219-22 (2004).

${ }^{31}$ G. Savo, A. Rainer, A. D'Epifanio, S. Licoccia and E. Traversa, "Co-Sintering of Dense YSZ Electrolyte Films on Porous NiO-YSZ Supporting Anodes for IT-SOFCs"; pp. 1031-6 in The Electrochemical Society Proceeding Series, Vol. 2005-07, Solid Oxide Fuel Cells IX (SOFC IX), Edited by S. C. Singhal and J. Mizusaki. The Electrochemical Society Proceeding Series, Pennington, NJ, 2005 . 